\title{
Self-rated health and mortality in the UK: results from the first comparative analysis of the England and Wales, Scotland, and Northern Ireland Longitudinal Studies
}

\author{
Harriet Young, Emily Grundy \\ London School of Hygiene \& Tropical Medicine \\ Dermot O'Reilly \\ Queen's University Belfast \\ Paul Boyle \\ University of St Andrews
}

Previous studies have shown that self-reported health indicators are predictive of subsequent mortaity, but that this association varies between populations and population sub-groups. For example, self-reported health is less predictive of mortality at older ages, has a stronger association with mortality for men than for women and is more predictive of mortality for those of lower than those of higher socio-economic status, particularly among middle aged working adults

This article explores this association using individual level, rather than ecological, data to see whether there are differences between the constituent countries of the UK in the relationship between self-reported health and subsequent mortality, and to investigate socio-economic inequalities in mortality more generally. Data are used from the three Census based longitudinal studies now available for England and Wales, Scotland and Northern Ireland. 


\section{Contents}

Introduction. 14

Previous research on associations between self-reported health and mortality 14

Methods 15

Descriptive results 19

Multivariate results. 20

Mortality 22

Summary of results...... 23

Discussion 24

Strengths and weaknesses of each analysis strategy...... 24

Acknowledgements 28

References 36

\section{List of figures}

Figure 1 Percentage of the population aged 35-74 with fair or poor self-rated health by age group, gender and country, ONS LS, SLS, NILS, 2001

Figure 2 Mortality rate by gender and country for those aged 35-49, ONS LS, SLS, NILS, 2001

Figure 3 Mortality rate by gender and country for those aged 50-64, ONS LS, SLS, NILS, 2001 20

Figure 4 Mortality rate by gender and country for those aged 65-74, ONS LS, SLS, NILS, 2001.

Figure 5 Mortality rate by gender and country for those aged 35-74, ONS LS, SLS, NILS, 2001 


\section{List of tables}

Table 1 Variables and categories used in individual level and aggregated datasets, ONS LS, SLS, NILS 2001

Table 2 Socio-demographic and socio-economic characteristics of the population aged 35-74 in England and Wales, Scotland and Northern Ireland, ONS LS, SLS, NILS 2001.

Table 3 Odds Ratios from logistic regression analysis of variations in the proportion of the population aged 35-74 with poor or fair self-rated health in 2001 by socio-demographic and socio-economic characteristics in England and Wales, Scotland and Northern Ireland. ONS LS, SLS, NILS 2001, using parallel datasets.. 25

Table 4 Odds Ratios from logistic regression analysis of variations in the proportion of the population aged 35-74 with poor or fair self-rated health in 2001 by socio-demographic and socio-economic characteristics in England and Wales, Scotland and Northern Ireland and for all countries combined. ONS LS, SLS, NILS 2001 using combined aggregated datasets.

Table 5 Rate ratios of mortality for the population aged $35-74$ by socio-demographic and socio-economic characteristics and health status in England and Wales, Scotland and Northern Ireland. ONS LS, SLS, NILS 2001 using parallel datasets... 29

Table 6 Rate ratios of mortality for the population aged 35-74 by socio-demographic and socio-economic characteristics and health status in England and Wales, Scotland and Northern Ireland, and for all countries combined. ONS LS, SLS, NILS 2001 using combined aggregated datasets. 


\section{Introduction}

There are now three census based record linkage studies covering all constituent parts of the UK. The oldest of these, the Office for National Statistics Longitudinal Study (ONS LS) which covers England and Wales, was established in the mid 1970s and includes individual level information from the 1971, 1981, 1991 and 2001 Censuses. The Northern Ireland Longitudinal Study (NILS) and the Scottish Longitudinal Study (SLS) were launched in 2006 and 2007 respectively. The SLS includes information from the 1991 and 2001 Censuses and NILS data from the 2001 Census. All three studies include linked data from vital registration systems, including mortality. This means that for the first time there is the potential to analyse differentials between the constituent elements of the UK, using information from large representative longitudinal studies including individual level information from both census and vital registration sources. All three sources are subject to stringent disclosure control safeguards and it is currently not possible to combine individual level data from them to create a UK dataset. However, comparative analysis may be carried out in two ways: firstly, by conducting separate parallel individual level analyses of the three studies and comparing results; and secondly, by appending datasets of aggregated counts of individual level data from each study and then analysing this combined dataset. In this paper we show results from using both methods to analyse socio-economic and country level differences in health and mortality. This is an important topic because of research and policy interest in health inequalities in the UK, and indications from previous research using ecological data that patterns of reporting health may differ between the constituent countries of the UK. ${ }^{1}$ We examine the strengths and weaknesses of each method for addressing this question and discuss the issues involved in working with the three datasets together.

\section{Previous research on associations between self-reported health and mortality}

Previous studies have shown that self-reported health indicators are predictive of subsequent mortality, ${ }^{2,3}$ but that this association varies between populations and population sub-groups. For example, self-reported health is less predictive of mortality at older ages; ${ }^{4}$ has a stronger association with mortality for men than for women; ${ }^{2}$ and is more predictive of mortality for those of lower than those of higher socio-economic status, particularly among middle aged working adults. ${ }^{4}$ Variations in reporting of self-rated health over time, ${ }^{5}$ and by geographic region, ${ }^{6,7,8}$ including by constituent country of the UK, have also been reported. Analysis of ecological associations using area level data has shown that for a given level of health, mortality rates are higher in Scotland than in Northern Ireland or Wales, an association that persists after control for socio-economic status. ${ }^{1}$ Thus the Scottish population has the highest mortality rates of the constituent countries of the UK, England the lowest, with Northern Ireland and Wales in between. However, on the evidence of self-reported health data, the population of Northern Ireland is less healthy than that of Scotland..$^{1,9}$ In this study, we are able to explore this association using individual level, rather than ecological, data to see whether there are differences between the constituent countries of the UK in the relationship between self-reported health and subsequent mortality, and to investigate socioeconomic inequalities in mortality more generally. 


\section{Methods}

\section{Data}

We use data from the three census based longitudinal studies now available for England and Wales, Scotland, and Northern Ireland. The ONS LS is a record linkage study of approximately one per cent of the population of England and Wales enumerated at the 1971 Census (some 500,000 people); sample members were selected on the basis of four birthdays in the year. Record linkage has been used to add information from subsequent censuses $(1981,1991,2001)$ and data from vital registration sources including births, to sample mothers and deaths of sample members and their spouses. ${ }^{10}$ While losing emigrants and the deceased, the sample has been maintained by the recruitment of new births and immigrants born on LS birthdays and so remains nationally representative.

The SLS is a 5.3 per cent representative sample of the Scottish population based on 20 birthdays in the year. A sample of approximately 265,000 SLS members was identified from the 1991 Census, with information linked in from the 2001 Census and other sources, including vital events, cancer registrations and hospital episodes. ${ }^{11}$

The NILS is also modelled on the ONS LS and includes approximately 500,000 sample members (around 28 per cent of the population of Northern Ireland). As with the ONS LS and the SLS, the sample is maintained by recruitment of new births and immigrants born on the 104 NILS birthdays. The NILS sample differs slightly from the ONS LS and SLS in that the initial sample was drawn from the Health Card Registration System and then linked to the census, whereas in the other two studies the initial sample was drawn from the census. Northern Ireland has a second census-based dataset that links the 2001 Census returns for the entire enumerated population to subsequently registered mortality data. However, the smaller NILS dataset was used for this study to maximise comparability with the other UK longitudinal studies.

All three studies have associated user support services, which facilitate use of the data for authorised researchers subject to disclosure control procedures. Further details of the data sets and these support services are available elsewhere. ${ }^{12}$ Access to anonymised individual level data is only possible in the respective statistical office safe setting (ONS for the ONS LS, The General Register Office for Scotland for the SLS, and the Northern Ireland Statistics and Research Agency for the NILS).

\section{Dataset development}

This study is based on analyses of those aged 35-74 at the 2001 Census and their mortality from the time of the 2001 Census until 30 June 2006. This age range was chosen because in younger groups levels of poor health and rates of mortality are very low, and in age groups 75 and over fewer indicators of socio-economic status are available in the data sets. We excluded those living in communal establishments, students not at their term time address and those lacking information on self-rated health or marital status in the 2001 Census. Proportions excluded because of non-response to these questions in the census accounted for 1.3 per cent of the ONS LS sample, 1.4 per cent of the SLS sample and 3.2 per cent of the NILS sample. We created datasets for both individual level and aggregated analyses. For the individual level analysis, we constructed equivalent separate datasets for the ONS LS, SLS and NILS. 


\section{Table $1 \quad$ Variables and categories used in individual level and aggregated datasets, ONS LS, SLS, NILS 2001}

\begin{tabular}{|c|c|c|}
\hline \multirow[t]{2}{*}{ Variable } & \multicolumn{2}{|c|}{ Variable categories } \\
\hline & Individual level datasets & Aggregated datasets \\
\hline Self rated health & $\begin{array}{l}\text { Good } \\
\text { Fairly good or not good }\end{array}$ & $\begin{array}{l}\text { Good } \\
\text { Fairly good or not good }\end{array}$ \\
\hline Gender & $\begin{array}{l}\text { Male } \\
\text { Female }\end{array}$ & $\begin{array}{l}\text { Male } \\
\text { Female }\end{array}$ \\
\hline Age/Age group & Age-single years & $\begin{array}{l}35-49 \\
50-64 \\
65-74\end{array}$ \\
\hline Marital status & $\begin{array}{l}\text { Married } \\
\text { Separated or divorced } \\
\text { Widowed } \\
\text { Never married }\end{array}$ & $\begin{array}{l}\text { Married } \\
\text { Not married }\end{array}$ \\
\hline Highest educational qualification & $\begin{array}{l}\text { Upper secondary or degree } \\
\text { Lower secondary } \\
\text { None } \\
\text { Other* (ONS LS only) } \\
\text { Missing }\end{array}$ & - \\
\hline NS-SEC & $\begin{array}{l}\text { Manager or professional } \\
\text { Intermediate ** } \\
\text { Lower } * * \\
\text { Never worked, unemployed, student, other } \\
\text { Missing }\end{array}$ & - \\
\hline Housing tenure & $\begin{array}{l}\text { Owner occupier } \\
\text { Social rental } \\
\text { Private rental or other } \\
\text { Missing }\end{array}$ & - \\
\hline Car access & $\begin{array}{l}\text { Yes } \\
\text { No } \\
\text { Missing }\end{array}$ & - \\
\hline Socio-economic status score ${ }^{* * * *}$ & - & $\begin{array}{l}0 \text { (Highest) } \\
1 \\
2 \\
3 \\
4 \\
5 \text { (Lowest) } \\
\text { Missing data }\end{array}$ \\
\hline Country & - & $\begin{array}{l}\text { England and Wales } \\
\text { Scotland } \\
\text { Northern Ireland }\end{array}$ \\
\hline
\end{tabular}

Notes:

* This category includes City and Guilds, RSA/OCR and BTEC/Edexcel qualifications which cover qualifications from entry to degree level.

** This group includes intermediate occupations, small employers and own account workers.

*** This group includes lower supervisory, technical, semi-routine and routine occupations.

For the aggregated analysis, we created aggregated count datasets for each LS and then combined them. In aggregated datasets such as these, cells comprise counts of individuals with a particular set of characteristics, (for example, being female, living in owner occupied housing and aged 35-49), rather than individuals themselves. Disclosure control guidelines meant that 


\section{Table 2 Socio-demographic and socio-economic characteristics of the population aged 35-74 in England and Wales, Scotland and Northern Ireland, ONS LS, SLS, NILS 2001}

\begin{tabular}{|c|c|c|c|c|}
\hline \multirow[b]{2}{*}{ Variable } & \multirow[b]{2}{*}{ Categories } & \multicolumn{3}{|c|}{ LS Sample } \\
\hline & & ONS LS & SLS & NILS \\
\hline \multirow[t]{2}{*}{ Age (years) } & Mean & 52.2 & 52.1 & 51.7 \\
\hline & Standard error & 0.022 & 0.032 & 0.025 \\
\hline \multirow[t]{3}{*}{ Age group (per cent) } & $35-49$ & 44.5 & 45.3 & 47.0 \\
\hline & $50-64$ & 37.4 & 36.8 & 36.2 \\
\hline & $65-74$ & 18.0 & 17.9 & 16.8 \\
\hline \multirow[t]{2}{*}{ Gender (per cent) } & Men & 48.8 & 47.9 & 48.3 \\
\hline & Women & 51.2 & 52.1 & 51.7 \\
\hline \multirow[t]{4}{*}{ Marital status (per cent) } & Married & 69.3 & 68.1 & 71.5 \\
\hline & Separated or divorced & 14.1 & 13.9 & 10.4 \\
\hline & Widowed & 5.9 & 6.9 & 6.6 \\
\hline & Never married & 10.7 & 11.0 & 11.5 \\
\hline \multirow{5}{*}{$\begin{array}{l}\text { Highest educational qualification } \\
\text { (per cent) }\end{array}$} & Upper secondary or degree & 22.5 & 35.2 & 18.1 \\
\hline & Lower secondary & 28.5 & 19.6 & 23.7 \\
\hline & None & 34.9 & 40.1 & 51.0 \\
\hline & Other & 8.7 & - & - \\
\hline & Missing & 5.5 & 5.2 & 7.3 \\
\hline \multirow[t]{5}{*}{ NS-SEC (per cent) } & Manager or professional & 30.0 & 28.9 & 25.2 \\
\hline & Intermediate occupations, small employers and own account & 19.8 & 18.9 & 19.8 \\
\hline & Lower supervisory, technical, semi-routine and routine & 33.5 & 39.7 & 35.1 \\
\hline & Never worked, unemployed, student, other & 3.8 & 3.4 & 5.4 \\
\hline & Missing & 12.9 & 9.2 & 14.6 \\
\hline \multirow[t]{4}{*}{ Housing tenure (per cent) } & Owner & 78.4 & 72.3 & 78.2 \\
\hline & Social housing tenant & 13.3 & 20.7 & 14.2 \\
\hline & Private housing tenant and other & 5.9 & 5.1 & 4.0 \\
\hline & Missing & 2.4 & 1.9 & 3.6 \\
\hline \multirow[t]{3}{*}{ Car access (per cent) } & Car & 83.9 & 77.5 & 82.7 \\
\hline & No car & 14.5 & 21.2 & 14.8 \\
\hline & Missing & 1.6 & 1.2 & 2.5 \\
\hline \multirow[t]{2}{*}{ Socio-economic score } & Mean (excluding those with missing values) & 2.4 & 2.5 & 2.7 \\
\hline & Standard error & 0.004 & 0.006 & 0.004 \\
\hline \multirow[t]{7}{*}{ Socio-economic score (per cent) } & 0 - Least disadvantaged & 13.6 & 18.5 & 11.5 \\
\hline & 1 & 13.4 & 10.7 & 9.7 \\
\hline & 2 & 14.7 & 12.8 & 12.3 \\
\hline & 3 & 16.5 & 13.6 & 14.9 \\
\hline & 4 & 15.4 & 16.0 & 19.2 \\
\hline & 5 - Most disadvantaged & 9.3 & 15.6 & 12.0 \\
\hline & Missing & 17.2 & 12.8 & 20.5 \\
\hline Total (per cent) & & 100 & 100 & 100 \\
\hline Number in analysis & & 254,918 & 122,753 & 192,251 \\
\hline
\end{tabular}

Source: Analysis of ONS LS, SLS and NILS 
cell counts of less than three were not permissible. ${ }^{13}$ For this reason in the aggregated analysis we used age groups rather than single year of age, combined marital status categories and created a socio-economic score derived from several variables rather than using each variable separately. This score was derived from separate indicators as follows: car access (0), no car access (1); home owner (0), private or social housing tenant (1); highest educational qualification upper secondary or degree (0), lower secondary or other (1), none (2); manager or professional (0), intermediate occupations (1), lower occupations, never worked, unemployed and students (2). Higher scores thus indicate a greater level of disadvantage.

The main advantage of using the aggregated data set was that we could also include a variable indicating country (England and Wales, Scotland, or Northern Ireland) and compare effects across these directly.

\section{Variables used in the analysis}

In all analyses we dichotomised self-rated health into a variable, distinguishing those who reported good health from those reporting 'fairly good' (termed 'fair' in some of the text below) or 'not good' health (hereafter referred to as 'poor' health). Mortality was measured from the census date, 29 April 2001, until 30 June 2006, the latest date that mortality data was available in all three data sources, giving five years and two months of follow-up.

Table 1 shows the variable categories used in the individual and aggregated analysis.

Demographic variables comprised single year of age, or age group, gender and marital status. Indicators of socio-economic status included individual-level highest educational qualification and National Statistics Socio-Economic Classification (NS SEC), derived from information on occupation and employment status, and two household-level variables, housing tenure and household access to one or more cars or vans. Variables and categories of variables were identical

\section{Figure 1 Percentage of the population aged 35-74 with fair or poor self-rated health by age group, gender and country, ONS LS, SLS, NILS, 2001}

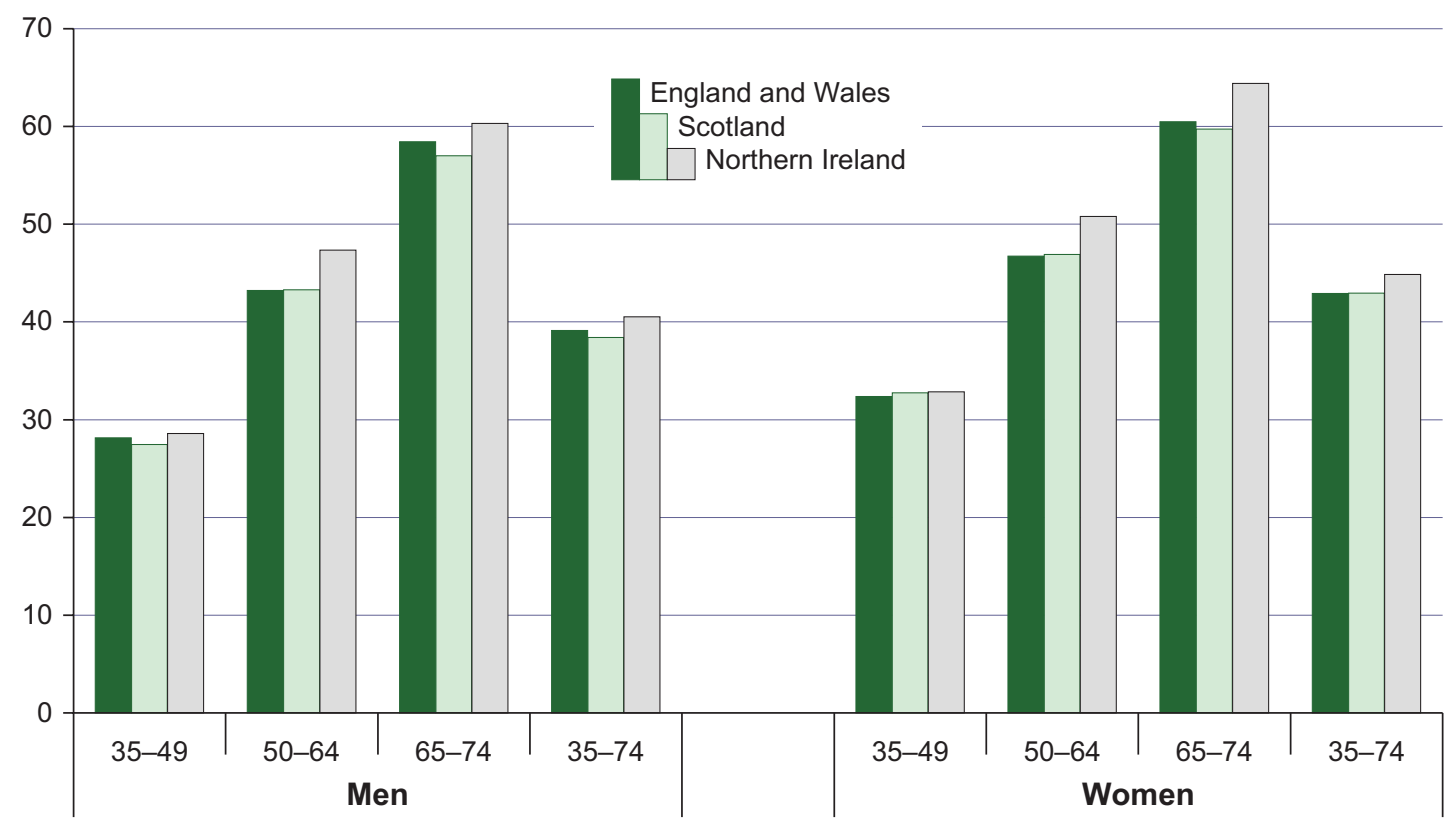

Source: ONS LS, SLS, NILS 2001 
in all three sources with the exception of highest educational qualification. The ONS LS education variable included an additional category of 'other' which the SLS and NILS did not have.

\section{Statistical methods}

We undertook preliminary descriptive analyses of the three samples using the individual level datasets. We used multivariate logistic regression to analyse differentials in self-reported health by socio-demographic characteristics using the individual level datasets, and by socio-demographic characteristics and country using the aggregated dataset. In the latter analysis we also present results for each country separately, in order to allow comparison between the two methods. Survival analysis, using Poisson regression, was undertaken to investigate associations between self-rated health and socio-demographic characteristics with subsequent mortality. Known emigrants were excluded from date of leaving the respective study. In both analyses of self-rated health and mortality we present results from models controlling for age and sex (Model 1), and results from models additionally controlling for socio-demographic characteristics (Model 2). In the aggregated analysis, country was included in both models. In the mortality analysis we also show results from a third model including self-rated health. All analysis was carried out in the statistical office safe settings and produced in accordance with disclosure control guidelines.

\section{Descriptive results}

Socio-demographic sample characteristics were broadly similar for England and Wales, Scotland and Northern Ireland (Table 2). The samples were similar in age and gender distribution, except that the Northern Ireland sample was slightly younger and included slightly more married and fewer divorced members. Differences between the three study samples in the distribution of sample members by educational level reflect both the separate identification of those with 'other' qualifications in England and Wales, and the different educational system in Scotland. Scotland had the highest proportion in the highest education category at 39 per cent, compared with 25 per cent in England and Wales, and 21 per cent in Northern Ireland. In the Northern Ireland sample, 51 per cent had none of the educational qualifications asked about, compared with 40 per cent of the Scottish sample, and 35 per cent of those in England and Wales. The Northern Ireland sample also included a slightly lower proportion in managerial and professional occupations and a slightly higher proportion in the category of never worked, unemployed, students or other. The proportion in lower supervisory, technical, semi-routine or routine occupations was largest in Scotland. In England and Wales, and Northern Ireland, 78 per cent of the sample were owner-occupiers compared with 72 per cent in Scotland, where a larger proportion lived in social housing. Those in Scotland were also slightly less likely to have access to a car or van. For the socio-economic score, used in the aggregated dataset analysis, the NILS sample had the highest proportion with missing values at 20 per cent, compared with 17 per cent in England and Wales and 13 per cent in Scotland (this illustrates one of the main disadvantages of using summary scores such as this - the high proportion with missing values on at least one of the variables used to construct it). The mean socio-economic score was lowest (representing a lower mean level of disadvantage) in England and Wales at 2.4, and highest in Northern Ireland with a score of 2.7. Scotland had the highest proportion of the sample in both the least and most disadvantaged categories.

Figure 1 shows the proportions with fairly good or not good self-rated health by gender, age group and country. These proportions were higher among women than men and higher in Northern Ireland than in Scotland or England and Wales. 


\section{Figure 2 Mortality rate by gender and country for those aged 35-49,} ONS LS, SLS, NILS, 2001

Rate per 1000

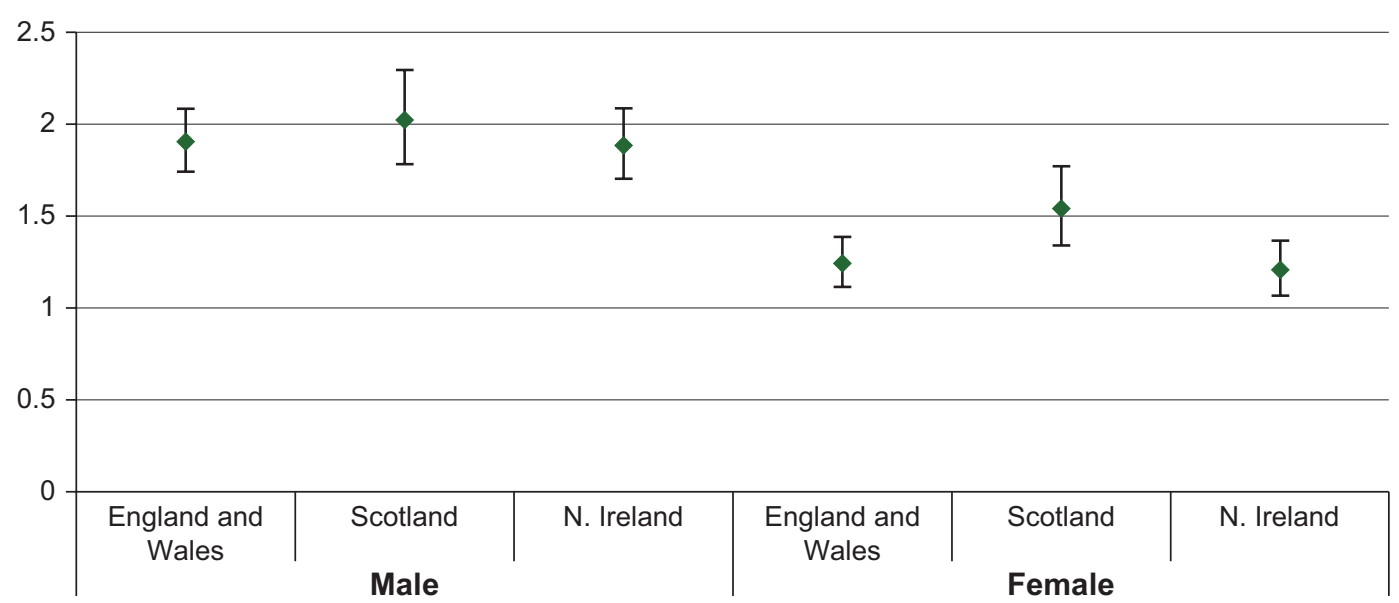

Figure 3 Mortality rate by gender and country for those aged 50-64, ONS LS, SLS, NILS, 2001

Rate per 1000

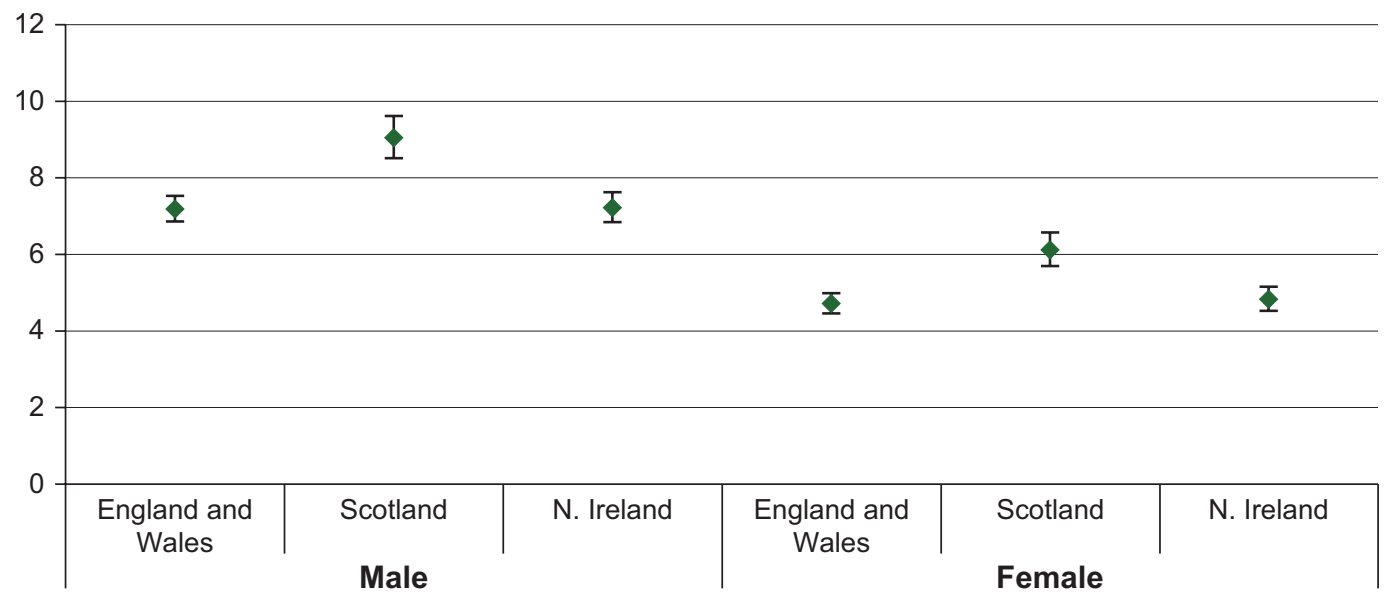

\section{Multivariate results}

\section{Self-rated health}

Table 3 and Table 4 show results from logistic regression analysis of differentials in the proportions reporting not good or fairly good self-rated health. In both individual level (Table 3 ) and aggregated analysis (Table 4), the odds of poorer self-rated health increased with age, and were significantly higher for women than men, although the gender difference was smaller once marital status and socio-economic status were controlled (Model 2). Inclusion of single year of age in the individual level models was a better control than in aggregated models which only included three age groups, as confirmed by a comparison of $r$-squared values for Model 1 individual level versus aggregated dataset analysis ( $r=0.042$ for individual analysis and $r=0.037$ for aggregated analysis, for Scotland). Unmarried people were more likely to report poor or fair self-rated health 


\section{Figure 4 Mortality rate by gender and country for those aged 65-74,} ONS LS, SLS, NILS, 2001

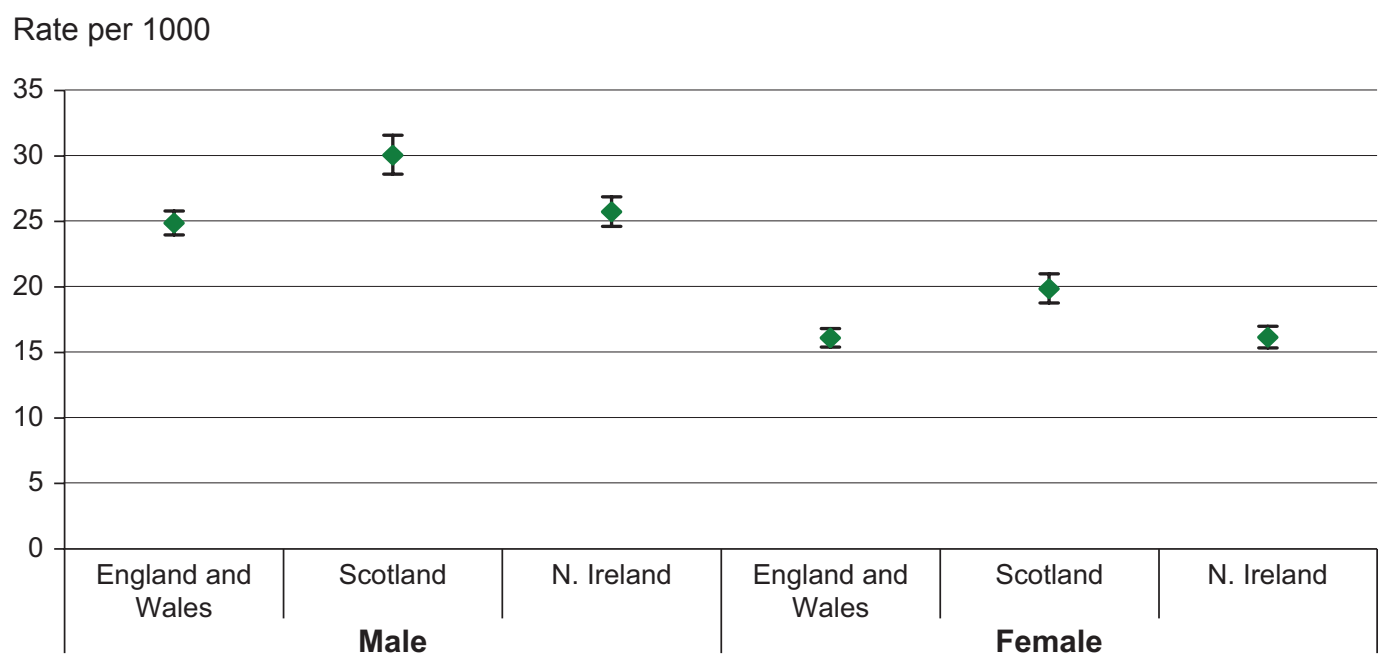

\section{Figure 5 Mortality rate by gender and country for those aged 35-74, ONS LS, SLS, NILS, 2001}

Rate per 1000

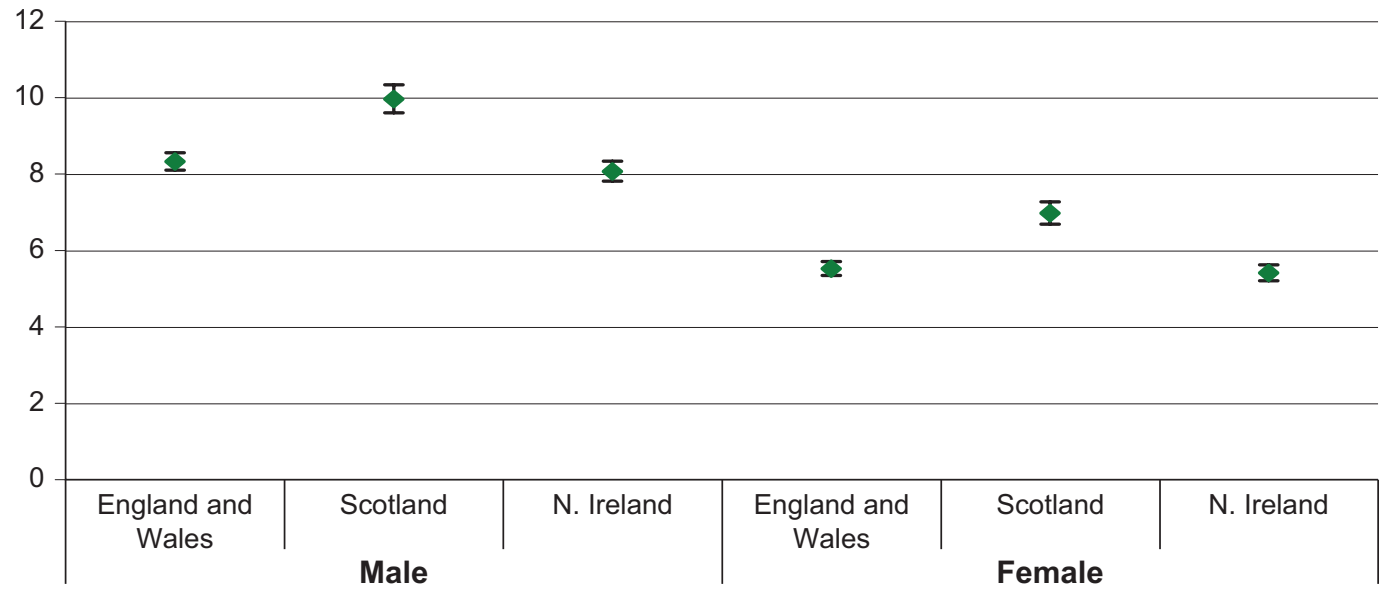

Source: ONS LS, SLS, NILS 2001

than the married. In the individual level analysis, in which we were able to distinguish between unmarried groups, we found that the separated, divorced and never married, but not the widowed, were significantly more likely to report not good or fairly good health than the married. In England and Wales, and Scotland the widowed were in fact marginally less likely to report not good or fairly good health than the married (Odds Ratio (OR) for England and Wales 0.96, 95 per cent confidence interval ( $\mathrm{Cl}$ ) 0.92-0.99). In all countries, those living in social housing, with no car, with no recorded educational qualification and in lower status occupations or not employed were the most likely to report not good or fairly good health. Reported health differentials by tenure appeared weaker in England and Wales than Scotland or Northern Ireland, whereas health differentials by NS-SEC appeared stronger in England and Wales than the other countries. For example, in England and Wales the odds of reporting not good or fairly good health among those who had never worked were 89 per cent higher than among managers or professionals 
(Cl 1.80-1.99), whereas the equivalent figure for Scotland was 55 per cent (Cl 1.44-1.67). Differentials in health status by educational level appeared smaller in Scotland than in England and Wales or Northern Ireland. In general, those with missing data were more likely than the most advantaged reference category to report not good or fairly good health, but did not appear to have the worst health. Results from analysis of the aggregated datasets (Table 4) showed that in each country increasing socio-economic score (indicating a higher level of disadvantage) was associated with poorer reported health. This association appeared to be the strongest in Northern Ireland, where those in the most disadvantaged category had 5.4 times the odds of reporting not good or fairly good self-rated health than the least disadvantaged ( $\mathrm{Cl} 5.19-5.66)$. In England and Wales the equivalent ratio was $4.4(\mathrm{Cl} 4.20-4.52)$ and in Scotland, 4.7 (4.47-4.89).

After adjusting for age and gender (Table 4, Model 2), those in Northern Ireland were 10 per cent more likely to report not good or fairly good health $(\mathrm{Cl} 1.09-1.11)$ than those in England and Wales, but there was no difference in this regard between Scotland and England and Wales. However, after additionally adjusting for marital status and socio-economic score (Model 2), the odds of reporting not good or fairly good self-rated health were slightly lower in Scotland than in England and Wales (OR 0.96, Cl 0.95-0.97).

\section{Mortality}

Figures 2, 3, 4 and 5 show mortality rates (deaths/person years of exposure) by country, age group and gender. In all age groups, men had higher rates of death than women. Those in Scotland had higher mortality rates than those in England and Wales or Northern Ireland, although in the youngest age group, in which the numbers of deaths observed were lowest, country differentials were small and not statistically significant. Age and sex standardisation demonstrated that for those aged 35-74, mortality rates in Scotland were 24 per cent higher than in England and Wales, and Northern Ireland's mortality rate was three per cent higher.

The main aim of the mortality analysis was to examine the association between health status and subsequent mortality in the three countries. Results show risks of death relative to a reference category. First, we briefly describe associations between other co-variates and mortality.

In all countries rate ratios of mortality increased with age, and were higher for men than for women, a difference that increased once marital status and socio-economic status were controlled for (Table 5). Although widows and widowers were no more likely to report not good or fairly good health than the married, in all countries their risks of death were higher. Indeed in England and Wales, relative risk ratios for the widowed were as high as for the separated, divorced and never married.

Consistent with the analysis of variations in self-rated health, mortality was highest for: tenants in social housing; those with no educational qualifications; and for those who had never worked, were unemployed, students or unclassified. Analysis of separate country aggregated datasets showed that there was a stronger association between socio-economic score and mortality in Northern Ireland than in the other countries. After control for self-rated health status, the association between socio-economic status and mortality weakened in all models and for all countries, but remained significant. In other words, while strongly related to survival, variation in health status only partly explained the association between socio-economic status and mortality. 
Analysis of the combined country aggregated dataset demonstrated that, after controlling for age group and gender (Table 6), the Scottish sample had significantly higher risks of death in the 5 years and two months following the 2001 Census than those in England and Wales (RR 1.23, CI 1.19-1.27). In Northern Ireland, mortality risks were not significantly different from England and Wales (RR 1.01 Cl 0.98-1.05). After control for socio-economic and marital status, the ratio for Scotland decreased marginally to $1.19(\mathrm{Cl} 1.15-1.23)$ and the rate ratio for Northern Ireland fell to 0.95 (Cl 0.92-0.98) indicating a significantly lower risk of death than in England and Wales (after control for marital status and socio-economic status). Additional control for self-rated health status (Model 3, all countries) did not alter the differences between countries in terms of mortality risks.

Those reporting not good or fairly good health in 2001 were more than twice as likely to die in the follow up period than those reporting good health, after controlling for socio-demographic and socio-economic factors (Model 3, Tables 5 and 6). However there was some variation in the association found using the different analysis strategies, with rate ratios associated with reporting poor or fair health being 7-9 per cent higher in the analysis of the individual level data than in the aggregated dataset. This is probably because of poorer control for socio-demographic and socio-economic factors in the analysis of the aggregated data, because of the need to use collapsed and less detailed indicators (age group rather than single year of age, two rather than four categories of marital status, and socio-economic score instead of separate socio-economic indicators). The association also varied by country. Using both analysis strategies we found that the association between health status and mortality was stronger in Scotland, after control for all other factors (aggregated analysis RR 3.01, Cl 2.81-3.22) than in England and Wales (RR 2.57 Cl 2.45-2.70) or Northern Ireland (RR 2.69 Cl 2.54-2.86).

\section{Summary of results}

Consistent with previous studies, these results showed that in all constituent countries of the UK, women were more likely than men to report not good or fairly good self-rated health, but were less likely to die in the follow up period. The never-married, divorced and separated were also more likely to report not good or fairly good health. All unmarried groups, including the widowed, were more likely to die in the follow up period than the married. Living in social housing, not having a car, having no educational qualifications and having never worked or being unemployed were all associated with higher levels of self-reported not good or fairly good health and with mortality, as was overall worse socio-economic score. There was some variation in the strength of these associations by country. Analysis using the socio-economic status score, for example, suggested that socio-economic differentials in health and mortality were larger in Northern Ireland than in Scotland or England and Wales.

We found a strong association between reporting of not good or fairly good health and mortality in all countries. This association appeared stronger in Scotland than Northern Ireland or England and Wales. This reflects our finding that members of the Scottish sample were no more likely to report not good or fairly good health than those in England and Wales, but that they had higher relative risks of death. This might indicate variations in pre-death health status in different parts of the UK or differences in the thresholds at which people in different parts of the UK report not having good health, or a combination of both. This would account both for the apparently lower risks of poorer health in Scotland, despite higher mortality, and the stronger association between self-rated health and mortality in Scotland. 


\section{Discussion}

In this article, we explored different strategies for comparative analysis of the ONS LS, the SLS and the NILS. All three studies have a very similar design and, even though each country has its own census form, most questions are identical and there is UK-wide co-ordination on census form development, data collection and data processing. ${ }^{14,15}$ Registration of deaths and processing of mortality data are also co-ordinated and comparable. There are, however, some minor differences in categories used which need consideration, namely the inclusion of an additional educational qualification category in the England and Wales Census. There are also differences in the distribution of the populations by educational and housing tenure indicators, reflecting the fact that in Scotland upper secondary level qualifications are gained a year earlier than in England, Wales or Northern Ireland and that the social housing stock (relative to population size) is far larger. These differences may explain why differentials in Scotland ,in health by education appeared weaker and by housing tenure stronger, than in England and Wales or Northern Ireland.

These country differences in education and housing tenure also influenced the comparability of the socio-economic score used in the aggregated datasets, which was based on all four socioeconomic indicators. For example Scotland had the highest proportion in the least disadvantaged category of the socio-economic score, which is likely to have been in part a result of the large proportion in the highest education category. Therefore, care must be taken in interpreting country differences, especially by socio-economic status. The other factor affecting comparability of results between countries is the differing proportions of non-respondents for the socio-economic status variables. This was a particular problem when combining socio-economic variables to produce the score used in analysis of the aggregated data set in which the proportions with missing data ranged from 13 per cent in Scotland to 20 per cent in Northern Ireland.

\section{Strengths and weaknesses of each analysis strategy}

Development of the individual level datasets involved standard application procedures, and so they were quicker and easier to prepare and use than the datasets for the aggregated analysis. There were no limits on the variables and categories used in the individual level datasets because all analysis was carried out in the safe setting for each longitudinal study. Preparation of the aggregated datasets was much more time consuming and logistically complex. It took time to obtain approval for release of aggregated NILS and SLS datasets from their respective safe settings to the ONS safe setting, where analysis of the aggregated data set was undertaken, and for the statistical offices to put into place secure data transfer systems.

Data set preparation also took much longer than for the individual level datasets, because of the iterative process necessary to ensure that all datasets met disclosure control protocols of each longitudinal study and ensure that they were also identical in terms of the variables and categories included.

Statistically, the individual level datasets provided more detailed, richer information than the aggregated datasets, including individual year of age instead of three age groups, four marital status groups instead of only two, and separate socio-economic variables instead of a combined socio-economic score. We therefore obtained more detailed country comparisons of the associations between different socio-economic and demographic indicators associations using the individual level datasets, and variables (particularly age) were more completely controlled than in 


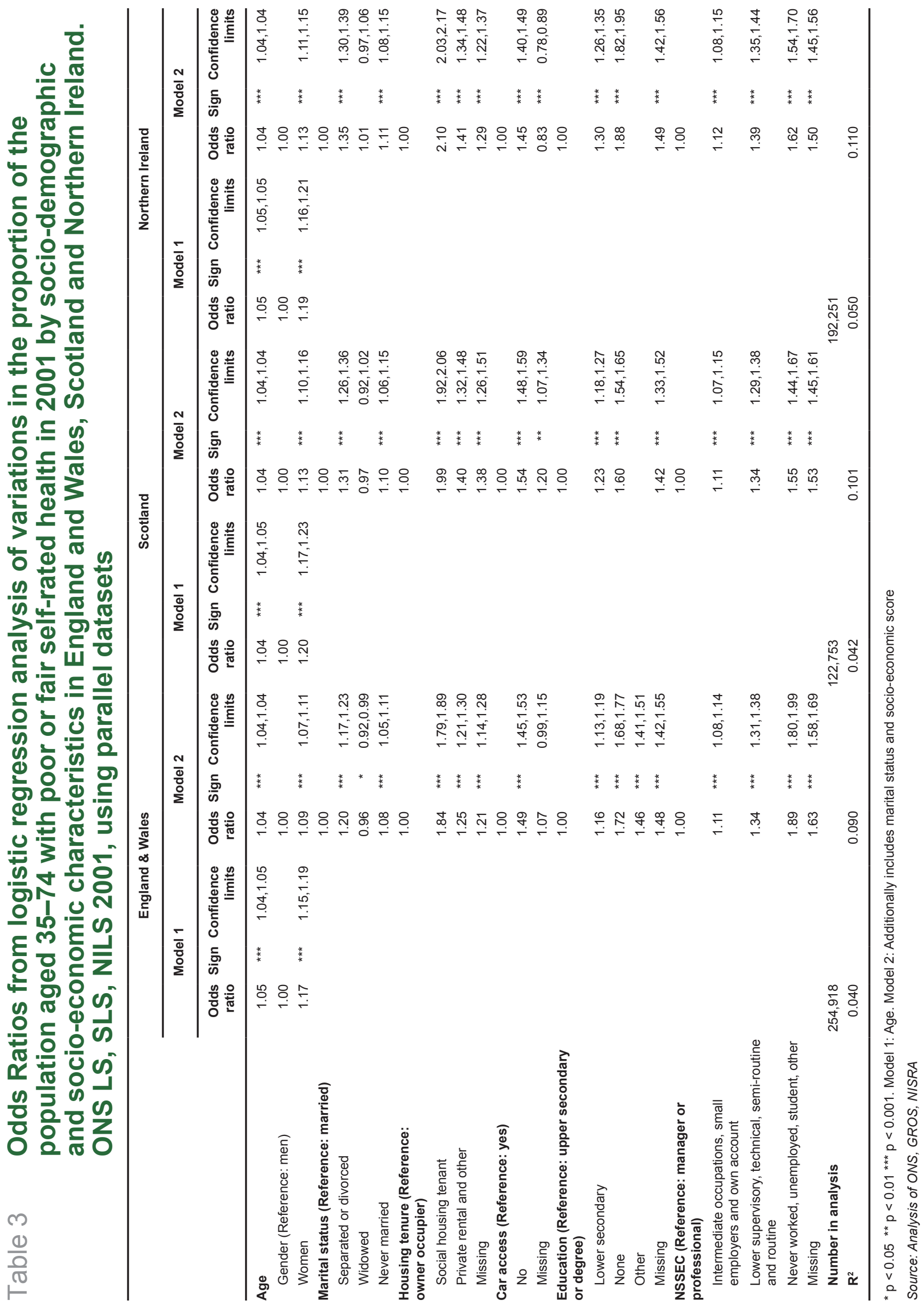




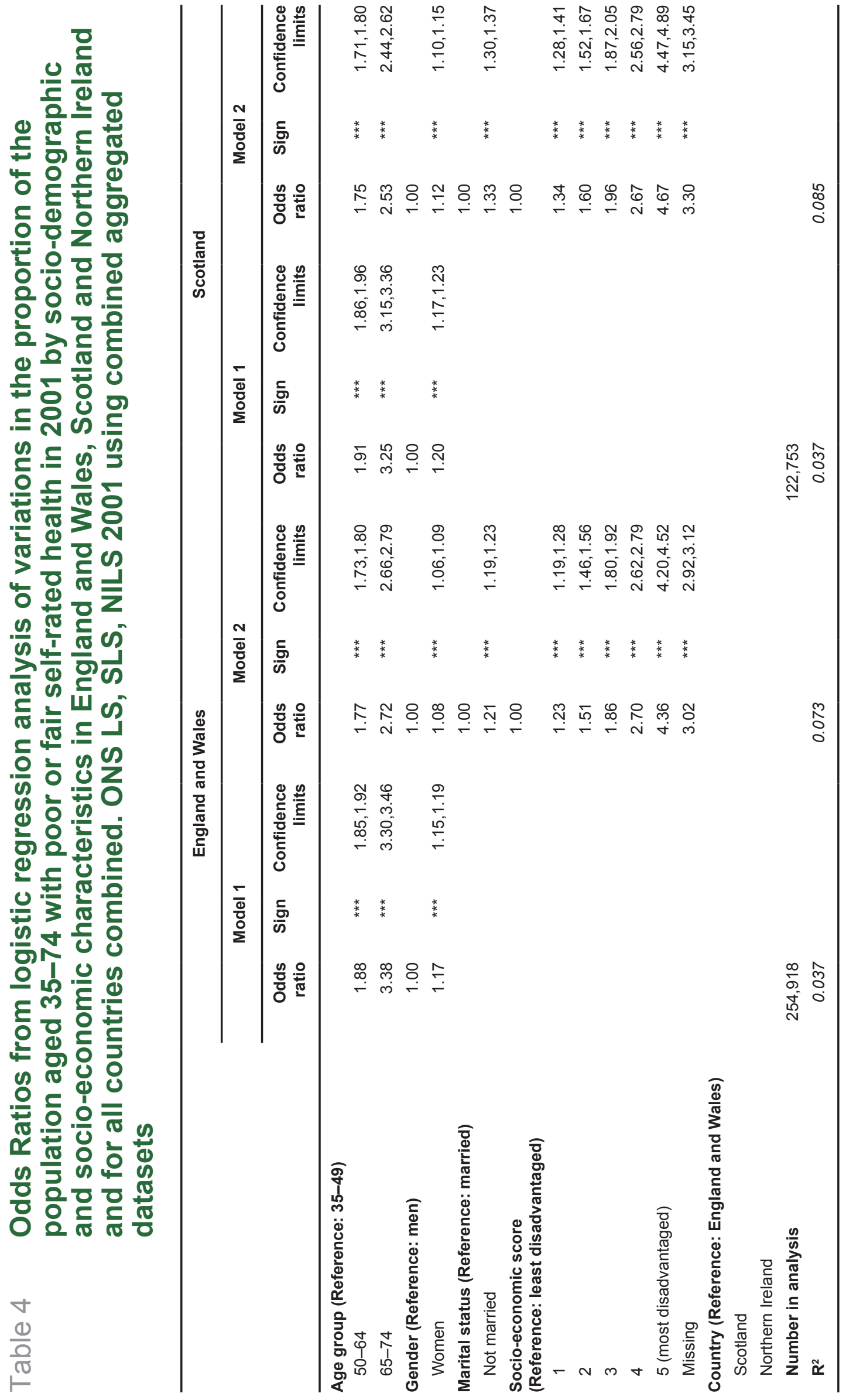




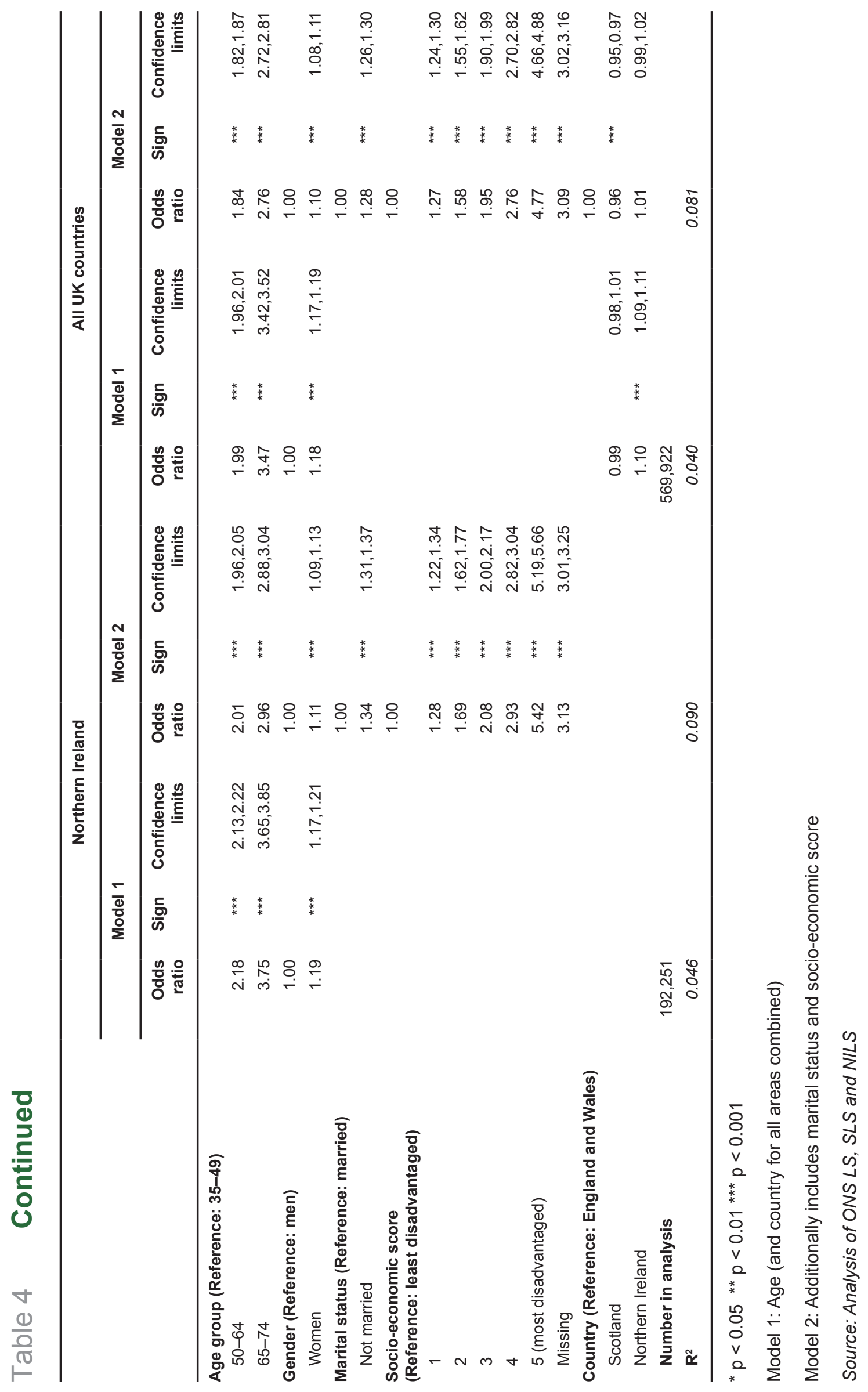


the aggregated dataset analyses, as confirmed by the r-squared values. Additionally, it was only possible to carry out an exploration of the characteristics of non-respondents to certain census questions using individual level and not aggregated datasets, because of small numbers that would have precluded clearance of such an aggregated dataset. There are therefore a number of advantages to using the individual level datasets. However, the major drawback was the difficulty in formally ascertaining country differences in the outcomes of interest. Using the combined aggregated datasets, we were easily able to ascertain country differences in health and mortality controlling for all co-variates and so add considerably to our knowledge of UK inequalities in health and mortality, and associations between self-rated health and mortality.

In summary, the individual level datasets provided much richer data with more variables and less time taken for dataset development (although for this project, this involved travel to three UK locations). However there was no easy way to make statistical comparisons between the countries. The combined aggregated datasets were logistically much more challenging and time consuming to prepare, had less variable detail, but enabled direct analysis of country comparisons. Both methods therefore have benefits, and the choice is likely to depend on the focus of research. Stringent disclosure control procedures on cell release of data from statistical office safe settings also means that this strategy would not be suitable for those wishing to analyse rare outcomes or more detailed variable categories.

Although it is not possible at present, the ability to combine subsets of individual level data from the three studies would combine the benefits of both of the methods currently possible - there is no question that this approach would be scientifically stronger. Given that the census offices pass census data between them, we would hope that it should be possible to develop relevant protocols and legal agreements to make the passing of longitudinal study data a future possibility. Finally, in the course of this project we developed a number of resources, including a technical working paper, comparative data dictionary and a comparative overview of database structure that we hope will be useful for others wishing to pursue UK comparative analyses. These are available via the web sites of all three user support services.

\section{Acknowledgements}

The research reported here was funded by the Economic and Social Research Council, grant reference RES-348-25-0013. The permission of the Office for National Statistics to use the Longitudinal Study is gratefully acknowledged, as is the help provided by staff of the Longitudinal Studies Centre - Scotland (LSCS); the Northern Ireland Longitudinal Study (NILS) and the Centre for Longitudinal Study Information and User Support (CeLSIUS) service. The LSCS is supported by the ESRC Census of Population Programme (Award Ref: RES-161-25-0001-01), the Scottish Funding Council, the Chief Scientist's Office and the Scottish Government; the NILS is funded by the Department of Health, Social Services and Public Health, and the Research and Development Office of the Health and Personal Services in Northern Ireland. CeLSIUS, is supported by the ESRC Census of Population Programme (Award Ref: RES-348-25-0004). The authors alone are responsible for the interpretation of the data. Census output is Crown copyright and is reproduced with the permission of the Controller of HMSO and the Queen's Printer for Scotland. 
Table 5 Rate ratios of mortality for the population aged 35-74 by socio-demographic and socio-economic characteristics and health status in England and Wales, Scotland and Northern Ireland. ONS LS, SLS, NILS 2001 using parallel datasets

\begin{tabular}{|c|c|c|c|c|c|c|c|c|c|}
\hline & \multicolumn{9}{|c|}{ England \& Wales } \\
\hline & \multicolumn{3}{|c|}{ Model 1} & \multicolumn{3}{|c|}{ Model 2} & \multicolumn{3}{|c|}{ Model 3} \\
\hline & $\begin{array}{l}\text { Rate } \\
\text { ratio }\end{array}$ & Sign & $\begin{array}{r}\text { Confidence } \\
\text { limits }\end{array}$ & $\begin{array}{l}\text { Rate } \\
\text { ratio }\end{array}$ & Sign & $\begin{array}{r}\text { Confidence } \\
\text { limits }\end{array}$ & $\begin{array}{l}\text { Rate } \\
\text { ratio }\end{array}$ & Sign & $\begin{array}{r}\text { Confidence } \\
\text { limits }\end{array}$ \\
\hline Age & 1.10 & *** & $1.10,1.11$ & 1.09 & *** & $1.09,1.10$ & 1.09 & *** & $1.08,1.09$ \\
\hline \multicolumn{10}{|l|}{ Gender (Reference: men) } \\
\hline Women & 0.65 & *** & $0.62,0.68$ & 0.58 & $* * *$ & $0.55,0.60$ & 0.58 & *** & $0.55,0.60$ \\
\hline \multicolumn{10}{|l|}{$\begin{array}{l}\text { Marital status } \\
\text { (Reference: married) }\end{array}$} \\
\hline Separated or divorced & & & & 1.26 & *** & $1.18,1.34$ & 1.23 & *** & $1.16,1.31$ \\
\hline Widowed & & & & 1.23 & $* * *$ & $1.14,1.32$ & 1.24 & *** & $1.16,1.33$ \\
\hline Never married & & & & 1.24 & $* * *$ & $1.15,1.34$ & 1.26 & $* * *$ & $1.16,1.36$ \\
\hline \multicolumn{10}{|l|}{$\begin{array}{l}\text { Housing tenure } \\
\text { (Reference: owner occupier) }\end{array}$} \\
\hline Social housing tenant & & & & 1.51 & $* * *$ & $1.43,1.60$ & 1.38 & *** & $1.30,1.46$ \\
\hline Private housing tenant and other & & & & 1.25 & *** & $1.14,1.37$ & 1.19 & $* * *$ & $1.09,1.30$ \\
\hline Missing & & & & 1.39 & *** & $1.23,1.56$ & 1.34 & *** & $1.19,1.51$ \\
\hline \multicolumn{10}{|l|}{ Car access (Reference: yes) } \\
\hline No & & & & 1.49 & *** & $1.41,1.58$ & 1.40 & *** & $1.32,1.48$ \\
\hline Missing & & & & 1.17 & * & $1.01,1.36$ & 1.17 & * & $1.00,1.35$ \\
\hline \multicolumn{10}{|l|}{$\begin{array}{l}\text { Education (Reference: upper } \\
\text { secondary or degree) }\end{array}$} \\
\hline Lower secondary & & & & 1.09 & & $1.00,1.19$ & 1.06 & & $0.98,1.16$ \\
\hline None & & & & 1.41 & *** & $1.30,1.52$ & 1.26 & *** & $1.17,1.36$ \\
\hline Other & & & & 1.27 & *** & $1.16,1.40$ & 1.17 & $* *$ & $1.07,1.29$ \\
\hline Missing & & & & 1.50 & $* * *$ & $1.36,1.65$ & 1.37 & *** & $1.24,1.51$ \\
\hline \multicolumn{10}{|l|}{$\begin{array}{l}\text { NSSEC (Reference: manager or } \\
\text { professional) }\end{array}$} \\
\hline $\begin{array}{l}\text { Intermediate occupations, small } \\
\text { employers and own account }\end{array}$ & & & & 1.05 & & $0.97,1.13$ & 1.02 & & $0.95,1.10$ \\
\hline $\begin{array}{l}\text { Lower supervisory, technical, } \\
\text { semi-routine and routine }\end{array}$ & & & & 1.11 & $* *$ & $1.04,1.19$ & 1.05 & & $0.98,1.12$ \\
\hline $\begin{array}{l}\text { Never worked, unemployed, } \\
\text { student, other }\end{array}$ & & & & 1.34 & *** & $1.21,1.50$ & 1.21 & *** & $1.09,1.35$ \\
\hline Missing & & & & 1.21 & *** & $1.12,1.31$ & 1.11 & ** & $1.03,1.20$ \\
\hline \multicolumn{10}{|l|}{$\begin{array}{l}\text { Self-rated health } \\
\text { (Reference: good health) }\end{array}$} \\
\hline Fair or poor health & & & & & & & 2.38 & *** & $2.26,2.50$ \\
\hline Total person years analysed & & & $1,251,009$ & & & & & & \\
\hline $\mathbf{R}^{2}$ & 0.09 & & & 0.11 & & & 0.12 & & \\
\hline
\end{tabular}




\section{Table 5 Continued}

\begin{tabular}{|c|c|c|c|c|c|c|c|c|c|}
\hline & \multicolumn{9}{|c|}{ Scotland } \\
\hline & \multicolumn{3}{|c|}{ Model 1} & \multicolumn{3}{|c|}{ Model 2} & \multicolumn{3}{|c|}{ Model 3} \\
\hline & $\begin{array}{l}\text { Rate } \\
\text { ratio }\end{array}$ & Sign & $\begin{array}{r}\text { Confidence } \\
\text { limits }\end{array}$ & $\begin{array}{l}\text { Rate } \\
\text { ratio }\end{array}$ & Sign & $\begin{array}{r}\text { Confidence } \\
\text { limits }\end{array}$ & $\begin{array}{l}\text { Rate } \\
\text { ratio }\end{array}$ & Sign & $\begin{array}{r}\text { Confidence } \\
\text { limits }\end{array}$ \\
\hline Age & 1.11 & $* * *$ & $1.10,1.11$ & 1.10 & $* * *$ & $1.09,1.10$ & 1.09 & $* * *$ & $1.09,1.09$ \\
\hline \multicolumn{10}{|l|}{ Gender (Reference: men) } \\
\hline Women & 0.67 & $* * *$ & $0.63,0.71$ & 0.61 & $* * *$ & $0.57,0.64$ & 0.60 & $* * *$ & $0.57,0.64$ \\
\hline \multicolumn{10}{|l|}{$\begin{array}{l}\text { Marital status } \\
\text { (Reference: married) }\end{array}$} \\
\hline Separated or divorced & & & & 1.36 & $* * *$ & $1.25,1.48$ & 1.30 & $* * *$ & $1.20,1.42$ \\
\hline Widowed & & & & 1.14 & $* *$ & $1.05,1.25$ & 1.15 & ** & $1.05,1.25$ \\
\hline Never married & & & & 1.28 & $* * *$ & $1.16,1.41$ & 1.29 & $* * *$ & $1.17,1.42$ \\
\hline \multicolumn{10}{|l|}{$\begin{array}{l}\text { Housing tenure } \\
\text { (Reference: owner occupier) }\end{array}$} \\
\hline Social housing tenant & & & & 1.52 & $* * *$ & $1.42,1.63$ & 1.34 & $* * *$ & $1.25,1.44$ \\
\hline Private housing tenant and other & & & & 1.36 & $* * *$ & $1.21,1.54$ & 1.26 & $* * *$ & $1.12,1.43$ \\
\hline Missing & & & & 1.44 & $* * *$ & $1.22,1.69$ & 1.34 & $* * *$ & $1.14,1.58$ \\
\hline \multicolumn{10}{|l|}{ Car access (Reference: yes) } \\
\hline No & & & & 1.40 & $* * *$ & $1.30,1.50$ & 1.28 & $* * *$ & $1.19,1.37$ \\
\hline Missing & & & & 1.25 & * & $1.02,1.53$ & 1.19 & & $0.97,1.46$ \\
\hline \multicolumn{10}{|l|}{$\begin{array}{l}\text { Education (Reference: upper } \\
\text { secondary or degree) }\end{array}$} \\
\hline Lower secondary & & & & 1.06 & & $0.95,1.18$ & 0.99 & & $0.89,1.11$ \\
\hline None & & & & 1.32 & $* * *$ & $1.21,1.45$ & 1.18 & $* * *$ & $1.07,1.29$ \\
\hline \multicolumn{10}{|l|}{ Other } \\
\hline Missing & & & & 1.38 & $* * *$ & $1.21,1.58$ & 1.26 & $* * *$ & $1.11,1.43$ \\
\hline \multicolumn{10}{|l|}{$\begin{array}{l}\text { NSSEC (Reference: manager or } \\
\text { professional) }\end{array}$} \\
\hline $\begin{array}{l}\text { Intermediate occupations, small } \\
\text { employers and own account }\end{array}$ & & & & 1.03 & & $0.92,1.14$ & 1.02 & & $0.92,1.14$ \\
\hline $\begin{array}{l}\text { Lower supervisory, technical, } \\
\text { semi-routine and routine }\end{array}$ & & & & 1.20 & $* * *$ & $1.09,1.32$ & 1.13 & * & $1.03,1.24$ \\
\hline $\begin{array}{l}\text { Never worked, unemployed, } \\
\text { student, other }\end{array}$ & & & & 1.36 & $* * *$ & $1.16,1.61$ & 1.27 & ** & $1.08,1.49$ \\
\hline Missing & & & & 1.26 & $* * *$ & $1.13,1.41$ & 1.17 & ** & $1.05,1.31$ \\
\hline \multicolumn{10}{|l|}{$\begin{array}{l}\text { Self-rated health } \\
\text { (Reference: good health) }\end{array}$} \\
\hline Fair or poor health & & & & & & & 2.82 & $* * *$ & $2.63,3.01$ \\
\hline Total person years analysed & & & 597,711 & & & & & & \\
\hline $\mathbf{R}^{2}$ & 0.10 & & & 0.13 & & & 0.15 & & \\
\hline
\end{tabular}




\section{Table 5 Continued}

\begin{tabular}{|c|c|c|c|c|c|c|c|c|c|}
\hline & \multicolumn{9}{|c|}{ Northern Ireland } \\
\hline & \multicolumn{3}{|c|}{ Model 1} & \multicolumn{3}{|c|}{ Model 2} & \multicolumn{3}{|c|}{ Model 3} \\
\hline & $\begin{array}{l}\text { Rate } \\
\text { ratio }\end{array}$ & Sign & $\begin{array}{r}\text { Confidence } \\
\text { limits }\end{array}$ & $\begin{array}{l}\text { Rate } \\
\text { ratio }\end{array}$ & Sign & $\begin{array}{r}\text { Confidence } \\
\text { limits }\end{array}$ & $\begin{array}{l}\text { Rate } \\
\text { ratio }\end{array}$ & Sign & $\begin{array}{r}\text { Confidence } \\
\text { limits }\end{array}$ \\
\hline Age & 1.11 & $* * *$ & $1.10,1.11$ & 1.10 & $* * *$ & $1.09,1.10$ & 1.09 & $* * *$ & $1.09,1.09$ \\
\hline \multicolumn{10}{|l|}{ Gender (Reference: men) } \\
\hline Women & 0.64 & $* * *$ & $0.61,0.67$ & 0.58 & $* * *$ & $0.55,0.61$ & 0.57 & $* * *$ & $0.54,0.60$ \\
\hline \multicolumn{10}{|l|}{$\begin{array}{l}\text { Marital status } \\
\text { (Reference: married) }\end{array}$} \\
\hline Separated or divorced & & & & 1.28 & $* * *$ & $1.18,1.40$ & 1.21 & $* * *$ & $1.11,1.32$ \\
\hline Widowed & & & & 1.13 & $* *$ & $1.05,1.23$ & 1.13 & ** & $1.04,1.22$ \\
\hline Never married & & & & 1.26 & $* * *$ & $1.16,1.36$ & 1.25 & $* * *$ & $1.16,1.35$ \\
\hline \multicolumn{10}{|l|}{$\begin{array}{l}\text { Housing tenure } \\
\text { (Reference: owner occupier) }\end{array}$} \\
\hline Social housing tenant & & & & 1.53 & $* * *$ & $1.43,1.63$ & 1.36 & $* * *$ & $1.27,1.46$ \\
\hline Private housing tenant and other & & & & 1.23 & $* * *$ & $1.09,1.39$ & 1.16 & * & $1.02,1.31$ \\
\hline Missing & & & & 1.27 & $* * *$ & $1.13,1.44$ & 1.21 & ** & $1.07,1.37$ \\
\hline \multicolumn{10}{|l|}{ Car access (Reference: yes) } \\
\hline No & & & & 1.47 & $* * *$ & $1.38,1.57$ & 1.39 & $* * *$ & $1.30,1.48$ \\
\hline Missing & & & & 1.12 & & $0.96,1.30$ & 1.16 & & $0.99,1.34$ \\
\hline \multicolumn{10}{|l|}{$\begin{array}{l}\text { Education (Reference: } \\
\text { upper secondary or degree) }\end{array}$} \\
\hline Lower secondary & & & & 1.16 & * & $1.03,1.31$ & 1.10 & & $0.98,1.24$ \\
\hline None & & & & 1.39 & $* * *$ & $1.25,1.54$ & 1.20 & $* * *$ & $1.08,1.33$ \\
\hline \multicolumn{10}{|l|}{ Other } \\
\hline Missing & & & & 1.49 & $* * *$ & $1.31,1.69$ & 1.32 & $* * *$ & $1.16,1.50$ \\
\hline \multicolumn{10}{|l|}{$\begin{array}{l}\text { NSSEC (Reference: manager or } \\
\text { professional) }\end{array}$} \\
\hline $\begin{array}{l}\text { Intermediate occupations, small } \\
\text { employers and own account }\end{array}$ & & & & 1.07 & & $0.97,1.18$ & 1.04 & & $0.95,1.15$ \\
\hline $\begin{array}{l}\text { Lower supervisory, technical, } \\
\text { semi-routine and routine }\end{array}$ & & & & 1.18 & $* * *$ & $1.08,1.29$ & 1.09 & * & $1.00,1.19$ \\
\hline $\begin{array}{l}\text { Never worked, unemployed, } \\
\text { student, other }\end{array}$ & & & & 1.43 & $* * *$ & $1.27,1.62$ & 1.31 & $* * *$ & $1.16,1.48$ \\
\hline Missing & & & & 1.27 & $* * *$ & $1.15,1.39$ & 1.16 & ** & $1.05,1.27$ \\
\hline \multicolumn{10}{|l|}{$\begin{array}{l}\text { Self-rated health } \\
\text { (Reference: good health) }\end{array}$} \\
\hline Fair or poor health & & & & & & & 2.50 & $* * *$ & $2.35,2.66$ \\
\hline Total person years analysed & & & 928,238 & & & & & & \\
\hline $\mathbf{R}^{2}$ & 0.11 & & & 0.13 & & & 0.15 & & \\
\hline
\end{tabular}

${ }^{*} \mathrm{p}<0.05{ }^{* *} \mathrm{p}<0.01{ }^{* * *} \mathrm{p}<0.001$

Model 1: Age.

Model 2: Additionally includes marital status and socio-economic score.

Model 3: Additionally includes health status indicator

Source: Analysis of ONS LS, SLS and NILS 
Table 6 Rate ratios of mortality for the population aged 35-74 by socio-demographic and socio-economic characteristics and health status in England and Wales, Scotland and Northern Ireland, and for all countries combined. ONS LS, SLS, NILS 2001 using combined aggregated datasets

\begin{tabular}{|c|c|c|c|c|c|c|c|c|c|}
\hline & \multicolumn{9}{|c|}{ England \& Wales } \\
\hline & \multicolumn{3}{|c|}{ Model 1} & \multicolumn{3}{|c|}{ Model 2} & \multicolumn{3}{|c|}{ Model 3} \\
\hline & $\begin{array}{l}\text { Rate } \\
\text { ratio }\end{array}$ & Sign & $\begin{array}{r}\text { Confidence } \\
\text { limits }\end{array}$ & $\begin{array}{l}\text { Rate } \\
\text { ratio }\end{array}$ & Sign & $\begin{array}{r}\text { Confidence } \\
\text { limits }\end{array}$ & $\begin{array}{l}\text { Rate } \\
\text { ratio }\end{array}$ & Sign & $\begin{array}{r}\text { Confidence } \\
\text { limits }\end{array}$ \\
\hline \multicolumn{10}{|l|}{$\begin{array}{l}\text { Age group } \\
\text { (Reference: } 35-49 \text { ) }\end{array}$} \\
\hline $50-64$ & 3.78 & $* * *$ & $3.50,4.09$ & 3.69 & $* * *$ & $3.41,3.99$ & 3.28 & $* * *$ & $3.04,3.55$ \\
\hline $65-74$ & 13.02 & $* * *$ & $12.08,14.03$ & 11.19 & $* * *$ & $10.37,12.07$ & 9.17 & $* * *$ & $8.50,9.90$ \\
\hline Gender (Reference: men) & 1.00 & & & 1.00 & & & 1.00 & & \\
\hline Women & 0.65 & $* * *$ & $0.62,0.68$ & 0.58 & $* * *$ & $0.56,0.61$ & 0.58 & $* * *$ & $0.56,0.61$ \\
\hline $\begin{array}{l}\text { Marital status } \\
\text { (Reference: married) }\end{array}$ & & & & 1.00 & & & 1.00 & & \\
\hline Not married & & & & 1.42 & $* * *$ & $1.36,1.48$ & 1.38 & $* * *$ & $1.32,1.45$ \\
\hline \multicolumn{10}{|l|}{$\begin{array}{l}\text { Socio-economic score } \\
\text { (Reference: least } \\
\text { disadvantaged) }\end{array}$} \\
\hline 1 & & & & 1.26 & $* * *$ & $1.12,1.41$ & 1.20 & $* *$ & $1.07,1.35$ \\
\hline 2 & & & & 1.39 & $* * *$ & $1.25,1.55$ & 1.26 & $* * *$ & $1.13,1.41$ \\
\hline 3 & & & & 1.57 & $* * *$ & $1.41,1.74$ & 1.35 & $* * *$ & $1.22,1.50$ \\
\hline 4 & & & & 1.94 & $* * *$ & $1.76,2.15$ & 1.56 & $* * *$ & $1.41,1.73$ \\
\hline 5 (most disadvantaged) & & & & 2.93 & $* * *$ & $2.65,3.25$ & 2.16 & $* * *$ & $1.95,2.40$ \\
\hline Missing & & & & 2.48 & $* * *$ & $2.25,2.73$ & 1.94 & $* * *$ & $1.76,2.14$ \\
\hline \multicolumn{10}{|l|}{$\begin{array}{l}\text { Self-rated health } \\
\text { (Reference: good health) }\end{array}$} \\
\hline Fair or poor health & & & & & & & 2.57 & $* * *$ & $2.45,2.70$ \\
\hline \multicolumn{10}{|l|}{$\begin{array}{l}\text { Country (Reference: } \\
\text { England \& Wales) }\end{array}$} \\
\hline \multicolumn{10}{|l|}{ Scotland } \\
\hline \multicolumn{10}{|l|}{ Northern Ireland } \\
\hline $\begin{array}{l}\text { Total person years } \\
\text { analysed }\end{array}$ & $1,251,009$ & & & & & & & & \\
\hline
\end{tabular}

${ }^{*} \mathrm{p}<0.05^{* *} \mathrm{p}<0.01^{* * *} \mathrm{p}<0.001$

Source: Analysis of ONS LS, SLS and NILS 


\section{Table 6 Continued}

\begin{tabular}{|c|c|c|c|c|c|c|c|c|c|}
\hline & \multicolumn{9}{|c|}{ Scotland } \\
\hline & \multicolumn{3}{|c|}{ Model 1} & \multicolumn{3}{|c|}{ Model 2} & \multicolumn{3}{|c|}{ Model 3} \\
\hline & $\begin{array}{l}\text { Rate } \\
\text { ratio }\end{array}$ & Sign & $\begin{array}{r}\text { Confidence } \\
\text { limits }\end{array}$ & $\begin{array}{l}\text { Rate } \\
\text { ratio }\end{array}$ & Sign & $\begin{array}{r}\text { Confidence } \\
\text { limits }\end{array}$ & $\begin{array}{l}\text { Rate } \\
\text { ratio }\end{array}$ & Sign & $\begin{array}{r}\text { Confidence } \\
\text { limits }\end{array}$ \\
\hline \multicolumn{10}{|l|}{$\begin{array}{l}\text { Age group } \\
\text { (Reference: 35-49) }\end{array}$} \\
\hline $50-64$ & 4.25 & $* * *$ & $3.83,4.72$ & 3.98 & $* * *$ & $3.58,4.42$ & 3.52 & $* * *$ & $3.17,3.91$ \\
\hline $65-74$ & 13.97 & $* * *$ & $12.63,15.45$ & 11.23 & $* * *$ & $10.14,12.45$ & 9.18 & $* * *$ & $8.29,10.18$ \\
\hline Gender (Reference: men) & 1.00 & & & 1.00 & & & 1.00 & & \\
\hline Women & 0.67 & $* * *$ & $0.64,0.71$ & 0.61 & $* * *$ & $0.58,0.65$ & 0.61 & $* * *$ & $0.57,0.64$ \\
\hline $\begin{array}{l}\text { Marital status } \\
\text { (Reference: married) }\end{array}$ & & & & 1.00 & & & 1.00 & & \\
\hline Not married & & & & 1.46 & $* * *$ & $1.38,1.55$ & 1.38 & $* * *$ & $1.30,1.46$ \\
\hline \multicolumn{10}{|l|}{$\begin{array}{l}\text { Socio-economic score } \\
\text { (Reference: least } \\
\text { disadvantaged) }\end{array}$} \\
\hline 1 & & & & 1.17 & * & $1.00,1.38$ & 1.10 & & $0.94,1.29$ \\
\hline 2 & & & & 1.41 & $* * *$ & $1.23,1.63$ & 1.24 & $* *$ & $1.08,1.43$ \\
\hline 3 & & & & 1.61 & $* * *$ & $1.41,1.84$ & 1.36 & $* * *$ & $1.19,1.56$ \\
\hline 4 & & & & 1.94 & $* * *$ & $1.72,2.19$ & 1.51 & $* * *$ & $1.34,1.71$ \\
\hline 5 (most disadvantaged) & & & & 2.97 & $* * *$ & $2.65,3.33$ & 2.06 & $* * *$ & $1.83,2.31$ \\
\hline Missing & & & & 2.70 & $* * *$ & $2.41,3.04$ & 2.01 & $* * *$ & $1.79,2.26$ \\
\hline \multicolumn{10}{|l|}{$\begin{array}{l}\text { Self-rated health } \\
\text { (Reference: good health) }\end{array}$} \\
\hline Fair or poor health & & & & & & & 3.01 & $* * *$ & $2.81,3.22$ \\
\hline \multicolumn{10}{|l|}{$\begin{array}{l}\text { Country (Reference: } \\
\text { England \& Wales) }\end{array}$} \\
\hline \multicolumn{10}{|l|}{ Scotland } \\
\hline \multicolumn{10}{|l|}{ Northern Ireland } \\
\hline $\begin{array}{l}\text { Total person years } \\
\text { analysed }\end{array}$ & 597,711 & & & & & & & & \\
\hline
\end{tabular}

${ }^{*} \mathrm{p}<0.05^{* *} \mathrm{p}<0.01^{* * *} \mathrm{p}<0.001$

Source: Analysis of ONS LS, SLS and NILS 


\section{Table 6 Continued}

\begin{tabular}{|c|c|c|c|c|c|c|c|c|c|}
\hline & \multicolumn{9}{|c|}{ Northern Ireland } \\
\hline & \multicolumn{3}{|c|}{ Model 1} & \multicolumn{3}{|c|}{ Model 2} & \multicolumn{3}{|c|}{ Model 3} \\
\hline & $\begin{array}{l}\text { Rate } \\
\text { ratio }\end{array}$ & Sign & $\begin{array}{r}\text { Confidence } \\
\text { limits }\end{array}$ & $\begin{array}{l}\text { Rate } \\
\text { ratio }\end{array}$ & Sign & $\begin{array}{r}\text { Confidence } \\
\text { limits }\end{array}$ & $\begin{array}{l}\text { Rate } \\
\text { ratio }\end{array}$ & Sign & $\begin{array}{r}\text { Confidence } \\
\text { limits }\end{array}$ \\
\hline \multicolumn{10}{|l|}{$\begin{array}{l}\text { Age group } \\
\text { (Reference: } 35-49 \text { ) }\end{array}$} \\
\hline $50-64$ & 3.90 & $* * *$ & $3.57,4.26$ & 3.69 & $* * *$ & $3.38,4.04$ & 3.20 & $* * *$ & $2.92,3.50$ \\
\hline $65-74$ & 13.54 & $* * *$ & $12.43,14.74$ & 11.27 & $* * *$ & $10.34,12.29$ & 8.99 & $* * *$ & $8.24,9.81$ \\
\hline Gender (Reference: men) & 1.00 & & & 1.00 & & & 1.00 & & \\
\hline Women & 0.64 & $* * *$ & $0.61,0.68$ & 0.58 & $* * *$ & $0.55,0.61$ & 0.57 & $* * *$ & $0.54,0.60$ \\
\hline $\begin{array}{l}\text { Marital status } \\
\text { (Reference: married) }\end{array}$ & & & & 1.00 & & & 1.00 & & \\
\hline Not married & & & & 1.41 & $* * *$ & $1.34,1.49$ & 1.35 & $* * *$ & $1.28,1.42$ \\
\hline \multicolumn{10}{|l|}{$\begin{array}{l}\text { Socio-economic score } \\
\text { (Reference: least } \\
\text { disadvantaged) }\end{array}$} \\
\hline 1 & & & & 1.26 & $* *$ & $1.06,1.50$ & 1.18 & & $0.99,1.41$ \\
\hline 2 & & & & 1.60 & $* * *$ & $1.37,1.87$ & 1.40 & $* * *$ & $1.20,1.64$ \\
\hline 3 & & & & 1.80 & $* * *$ & $1.56,2.08$ & 1.49 & $* * *$ & $1.29,1.72$ \\
\hline 4 & & & & 2.12 & $* * *$ & $1.84,2.43$ & 1.62 & $* * *$ & $1.41,1.86$ \\
\hline 5 (most disadvantaged) & & & & 3.44 & $* * *$ & $2.99,3.95$ & 2.37 & $* * *$ & $2.06,2.72$ \\
\hline Missing & & & & 2.71 & $* * *$ & $2.37,3.10$ & 2.03 & $* * *$ & $1.77,2.33$ \\
\hline \multicolumn{10}{|l|}{$\begin{array}{l}\text { Self-rated health } \\
\text { (Reference: good health) }\end{array}$} \\
\hline Fair or poor health & & & & & & & 2.69 & $* * *$ & $2.54,2.86$ \\
\hline \multicolumn{10}{|l|}{$\begin{array}{l}\text { Country (Reference: } \\
\text { England \& Wales) }\end{array}$} \\
\hline \multicolumn{10}{|l|}{ Scotland } \\
\hline \multicolumn{10}{|l|}{ Northern Ireland } \\
\hline $\begin{array}{l}\text { Total person years } \\
\text { analysed }\end{array}$ & 942,434 & & & & & & & & \\
\hline
\end{tabular}

${ }^{*} \mathrm{p}<0.05^{* *} \mathrm{p}<0.01^{* * *} \mathrm{p}<0.001$

Source: Analysis of ONS LS, SLS and NILS 


\section{Table 6 Continued}

All

\begin{tabular}{|c|c|c|c|c|c|c|c|c|}
\hline \multicolumn{3}{|c|}{ Model 1} & \multicolumn{3}{|c|}{ Model 2} & \multicolumn{3}{|c|}{ Model 3} \\
\hline $\begin{array}{l}\text { Rate } \\
\text { ratio }\end{array}$ & Sign & $\begin{array}{r}\text { Confidence } \\
\text { limits }\end{array}$ & $\begin{array}{l}\text { Rate } \\
\text { ratio }\end{array}$ & Sign & $\begin{array}{r}\text { Confidence } \\
\text { limits }\end{array}$ & $\begin{array}{l}\text { Rate } \\
\text { ratio }\end{array}$ & Sign & $\begin{array}{r}\text { Confidence } \\
\text { limits }\end{array}$ \\
\hline
\end{tabular}

Age group

(Reference: 35-49)

\begin{tabular}{|c|c|c|c|c|c|c|c|c|c|}
\hline $50-64$ & 3.93 & *** & $3.74,4.14$ & 3.76 & *** & $3.57,3.96$ & 3.31 & *** & $3.14,3.49$ \\
\hline $65-74$ & 13.41 & *** & $12.77,14.09$ & 11.24 & *** & $10.70,11.82$ & 9.12 & *** & $8.67,9.59$ \\
\hline Gender (Reference: men) & 1.00 & & & & & & & & \\
\hline Women & 0.65 & *** & $0.64,0.67$ & 0.59 & *** & $0.57,0.60$ & 0.58 & *** & $0.57,0.60$ \\
\hline \multicolumn{10}{|l|}{$\begin{array}{l}\text { Marital status } \\
\text { (Reference: married) }\end{array}$} \\
\hline Not married & & & & 1.43 & *** & $1.39,1.47$ & 1.37 & *** & $1.33,1.41$ \\
\hline \multicolumn{10}{|l|}{$\begin{array}{l}\text { Socio-economic score } \\
\text { (Reference: least } \\
\text { disadvantaged) }\end{array}$} \\
\hline 1 & & & & 1.25 & *** & $1.15,1.35$ & 1.18 & *** & $1.09,1.28$ \\
\hline 2 & & & & 1.45 & *** & $1.34,1.56$ & 1.29 & $* * *$ & $1.20,1.39$ \\
\hline 3 & & & & 1.64 & $* * *$ & $1.52,1.76$ & 1.39 & $* * *$ & $1.29,1.49$ \\
\hline 4 & & & & 1.98 & *** & $1.85,2.12$ & 1.56 & *** & $1.46,1.67$ \\
\hline 5 (most disadvantaged) & & & & 3.06 & *** & $2.87,3.28$ & 2.18 & *** & $2.04,2.33$ \\
\hline Missing & & & & 2.57 & *** & $2.41,2.75$ & 1.97 & *** & $1.85,2.10$ \\
\hline \multicolumn{10}{|l|}{$\begin{array}{l}\text { Self-rated health } \\
\text { (Reference: good health) }\end{array}$} \\
\hline Fair or poor health & & & & & & & 2.71 & *** & $2.62,2.80$ \\
\hline $\begin{array}{l}\text { Country (Reference: } \\
\text { England \& Wales) }\end{array}$ & 1.00 & & & & & & & & \\
\hline Scotland & 1.23 & *** & $1.19,1.27$ & 1.19 & *** & $1.15,1.23$ & 1.2 & *** & $1.16,1.24$ \\
\hline Northern Ireland & 1.01 & & $0.98,1.05$ & 0.95 & ** & $0.92,0.98$ & 0.94 & *** & $0.91,0.97$ \\
\hline $\begin{array}{l}\text { Total person years } \\
\text { analysed }\end{array}$ & $2,791,153$ & & & & & & & & \\
\hline
\end{tabular}

${ }^{*} \mathrm{p}<0.05{ }^{* *} \mathrm{p}<0.01{ }^{* * *} \mathrm{p}<0.001$

Source: Analysis of ONS LS, SLS and NILS 


\section{References}

1 O'Reilly D, Rosato M et al. (2005) 'Self reported health and mortality: ecological analysis based on electoral wards across the United Kingdom'. British Medical Journal 331: 938-9.

2 Idler E and Benyamini Y (1997) 'Self-rated health and mortality: a review of twenty-seven community studies'. Journal of Health and Social Behaviour 38: 21-37.

3 DeSalvo K B, Bloser N et al. (2005). 'Mortality Prediction with a Single General Self-Rated Health Question: A Meta-Analysis'. Journal of General Internal Medicine 21(3): 267-275.

4 Singh-Manoux A, Dugravot A et al. (2007) 'The association between self-rated health and mortality in different socioeconomic groups in the GAZEL cohort study'. International Journal of Epidemiology 36: 1222-1228.

5 Mitchell R (2005) 'Commentary: The decline of death - how do we measure and interpret changes in self-reported health across cultures and time ?' International Journal of Epidemiology 34: 306-308.

6 Rees P (1993) 'Counting people: past, present and future'. University of Leeds. Review 36: 247-273.

7 Boyle P J, Gatrell A C et al. (1999) 'Self-reported limiting long term illness, relative deprivation, and population stability in England and Wales'. Social Science and Medicine 49: 791-9.

8 Bardage C, Pluijm S et al. (2005) 'Self-rated health among older adults: a cross national comparison'. European Journal of Ageing 2: 149-158.

9 Breakwell C and Bajekal M (2006) 'Health expectancies in the UK and its constituent countries, 2001'. Health Statistics Quarterly 29: 18-25.

10 Hattersley L and Creeser R (1995) 'Longitudinal Study 1971-1991. History, organisation and quality of data'. Series LS no. 7. London HMSO.

11 Boyle P J, Feijten P, Feng Z, Hattersley L, Huang Z, Nolan J and Raab G (2008) 'Cohort Profile: The Scottish Longitudinal Study (SLS)'. International Journal of Epidemiology 38: 385-392.

12 More information available at: http://census.ac.uk/

13 Under the NILS Disclosure Control Policy, outputs containing tabular data with counts lower than ten are not released from the secure setting. However, as an exception and to facilitate analysis by the research team, it was agreed that NILS would securely transfer data with counts lower than ten to the ONS LS secure setting, though the final product contains no counts lower than ten.

14 UK Census Committee (1999) 'The 2001 Census of Population'. UK Census Committee, HMSO.

15 Office for National Statistics (2005) 'Census 2001 General report for England and Wales', HMSO. Available at: www.statistics.gov.uk/census2001/cn_143.asp 